\title{
O gênero Eugenia L. (Myrtaceae) na planície de alagável do Alto Rio Paraná, Estados de Mato Grosso do Sul e Paraná, Brasil ${ }^{1}$
}

\author{
Mariza Barion Romagnolo ${ }^{2,4}$ e Maria Conceição de Souza ${ }^{3}$
}

Recebido em 13/01/2005. Aceito em 6/01/2006

\begin{abstract}
RESUMO - (O gênero Eugenia L. (Myrtaceae) na planície de alagável do Alto Rio Paraná, Estados de Mato Grosso do Sul e Paraná, Brasil). Foi realizado o levantamento das espécies de Eugenia L. da planície alagável do Alto Rio Paraná, Estados de Mato Grosso do Sul e Paraná $\left(22^{\circ} 40^{\prime}\right.$ a $22^{\circ} 55^{\prime} \mathrm{S}$ e $53^{\circ} 10^{\prime}$ a $\left.53^{\circ} 40^{\prime} \mathrm{W}\right)$. Esta área localiza-se no domínio da Floresta Estacional Semidecidual e apresenta formações ripárias ao longo do rio Paraná, de suas ilhas e de seus tributários. As espécies registradas foram: Eugenia egensis DC., E. florida DC., E. hyemalis Cambess., E. klappenbachiana Mattos \& D. Legrand, E. moraviana O. Berg, E. pyriformis Cambess., E. ramboi D. Legrand, E. repanda O. Berg., E. sulcata Spring. ex Mart. e E. uniflora L. Os meses que apresentaram o maior número de espécies em floração e frutificação foram respectivamente, setembro e novembro. Eugenia florida, E. hyemalis e E. repanda apresentam ampla distribuição na área, enquanto que E. ramboi e E. sulcata foram encontradas somente na margem esquerda do rio Paraná. É fornecida uma chave para a identificação das espécies, acompanhada de ilustrações e descrições das mesmas, além de informações sobre o período de floração, frutificação e distribuição na área estudada.
\end{abstract}

Palavras-chave: Myrtaceae, Eugenia, florística, vegetação ripária, rio Paraná

ABSTRACT - (The genus Eugenia L. (Myrtaceae) on the Upper Paraná River floodplain, Mato Grosso do Sul and Paraná States, Brazil). A floristic survey of Eugenia L. species of the Upper Paraná River floodplain in Mato Grosso do Sul and Paraná States, Brazil $\left(22^{\circ} 40^{\prime}-22^{\circ} 55^{\prime} \mathrm{S} ; 53^{\circ} 10^{\prime}-53^{\circ} 40^{\prime} \mathrm{W}\right)$ is presented. The study area is covered by Seasonal Semideciduous Forest, with riparian formations along the Paraná River and its islands and tributaries. The following species were identified: E. egensis DC., E. florida DC., E. hyemalis Cambess., E. klappenbachiana Mattos \& D. Legrand, E. moraviana O. Berg, E. pyriformis Cambess., E. ramboi D. Legrand, E. repanda O.Berg., E. sulcata Spring. ex Mart., and E. uniflora L. The greatest number of species in flower or fruit was detected in September and November, respectively. Eugenia florida, E. hyemalis and E. repanda are widely distributed in the study area, whereas E. ramboi and E. sulcata were observed only on the left bank of the Paraná River. An identification key, illustrations, descriptions, phenology and distribution of the species are provided.

Key words: Myrtaceae, Eugenia, floristics, riparian vegetation, Paraná River

\section{Introdução}

A família Myrtaceae encontra-se representada no Brasil por cerca de 23 gêneros e mil espécies (Landrum \& Kawasaki 1997). Aproximadamente um terço dessas espécies pertence ao gênero Eugenia, que apresenta ampla distribuição, ocorrendo desde o México até a Argentina, sendo ainda incerto o número de espécies que apresenta (McVaugh 1968; Johnson \& Briggs 1984).

Uma das mais importantes contribuições sobre esse gênero foi publicada por Berg (1857-1859), onde estão descritas cerca de 500 espécies. Posteriormente, novas espécies foram descritas por outros autores, mas o gênero, como um todo, não foi mais estudado.
O gênero Eugenia encontra-se bem representado nas diversas formações vegetacionais do Brasil, não apenas quanto à riqueza específica, mas também quanto à abundância e freqüência de suas espécies (Klein 1984; Peixoto \& Gentry 1990; Leitão Filho 1993; Barroso \& Peron 1994; Chagas e Silva et al. 1995; Rodrigues \& Nave 2000; Arantes \& Monteiro 2002). Muitas dessas espécies são ricas em óleos essenciais e taninos, e são freqüentemente utilizadas na medicina popular (Pio Corrêa 1984; Neves \& Donato 1989; Pott \& Pott 1994; Lunardi et al. 2001). São, também, fornecedoras de frutos comestíveis, podendo-se citar E. involucrata DC. (cereja-do-mato), E. pyriformis Cambess. (uvaia), E. neosilvestres Sobral (grumixama) e E. uniflora L. (pitanga), que são

\footnotetext{
Parte da Tese de Doutorado da primeira Autora (PEA/UEM)

2 Universidade Paranaense Campus Paranavaí, Avenida Humberto Bruning 360, 87706-030 Parnavaí, PR, Brasil

3 Universidade Estadual de Maringá, Departamento de Biologia, Nupélia, Avenida Colombo 5790, 87020-900 Maringá, PR, Brasil

4 Autor para correspondência: mariza@unipar.br
} 
apreciadas tanto pelo homem como pela fauna silvestre (Lorenzi 1998; Pott \& Pott 1994; Marchiori \& Sobral 1997).

Considerando essa importância e a riqueza específica relativamente elevada que a família Myrtaceae apresenta em formações vegetacionais ripárias, o presente estudo teve por objetivo o levantamento das espécies de Eugenia para a planície alagável do Alto Rio Paraná, fornecendo meios para a sua identificação, informações sobre períodos de florescimento e frutificação, e distribuição na área estudada.

\section{Material e métodos}

A área de estudo localiza-se no trecho do Alto Rio Paraná denominado de planície alagável. Abrange áreas dos Municípios de Porto Rico, São Pedro do Paraná e Marilena, no Estado do Paraná, e de Bataiporã, Jateí e Taquaruçu, em Mato Grosso do Sul, tendo como limites aproximados $22^{\circ} 40^{\prime}$ a $22^{\circ} 55^{\prime} \mathrm{S}$ e $53^{\circ} 10^{\prime}$ a $53^{\circ} 40^{\prime} \mathrm{W}$. Inclui ilhas e áreas marginais do rio Paraná e de seus tributários, os rios Baía e Ivinheima, bem como os canais Corutuba e Poitã, para a margem direita, e o ribeirão São Pedro e o córrego Caracu, para a margem esquerda. O rio Paraná, nesse trecho, apresenta padrão geomorfológico multicanal e abriga diversos subambientes fluviais, tais como pântanos, lagoas, canais secundários e diques marginais, formando extensa planície de inundação que se desenvolve na margem direita. A margem esquerda, na maioria das vezes, apresenta barrancos altos e estáveis, de até $15 \mathrm{~m}$ de altura (Souza Filho \& Stevaux 1997).

O clima da região, de acordo com a classificação de Köppen, é do tipo Cfa (Maack 1968; Paraná 1987). As chuvas distribuem-se durante todos os meses do ano, com maior volume no período de setembro a dezembro, e menor de junho a agosto, sendo sempre superiores a $30 \mathrm{~mm} / \mathrm{mês}$ (Iapar 1994). O relevo é caracterizado por áreas de planície, com altitudes variando entre 230 a $290 \mathrm{~m}$ (Stevaux 1994). A ocorrência de Latossolos Vermelhos Distróficos de textura média, de Alissolos de textura média e de Gleissolos, é citada para a margem esquerda, enquanto que solos aluviais eutróficos, de textura argilosa, classificados como Neossolos, são citados para a margem direita (Embrapa 1984; 1999). A vegetação ripária, descrita sucintamente por Souza et al. (1997; 2004), encontra-se entre o domínio da Floresta Estacional Semidecidual e do Cerrado, apresentando formações florestais e várzeas, além de vastas extensões de pastagem.

O material estudado, proveniente de coletas mensais realizadas nos anos de 1999-2002, foi incorporado ao acervo do Herbário da Universidade Estadual de Maringá (HUEM). Foram incluídos no estudo outros materiais pertencentes ao HUEM. Também foram consultadas as coleções do Herbário da Universidade Estadual de Londrina (FUEL) e do Herbário do Museu Botânico Municipal de Curitiba (MBM), porém não foram encontrados materiais da região estudada. Para cada espécie foi citada apenas uma coleta por local, em "material selecionado". Uma lista completa do material examinado encontra-se à disposição com as autoras. As descrições do gênero e espécies foram baseadas apenas nos materiais coletados na planície alagável do Alto Rio Paraná. A nomenclatura utilizada para descrever a morfologia foliar baseou-se em Hickey (1974) e Radford et al. (1974) e, para inflorescência, em Briggs \& Johnson (1979). Os nomes populares foram baseados em Legrand \& Klein (1969), Bernardi (1985) e Rotman (1995).

\section{Resultados e discussão}

Eugenia L., Sp. pl. 1(1): 470. 1753.

Arbusto a árvore, ca. 3-12 m alt. Flores em racemos, dicásios ou isoladas; antopódio presente; profilos livres, persistentes ou caducos; botões florais abertos; sépalas 4, freqüentemente desiguais, 2 maiores e 2 menores; pétalas 4, semelhantes; estames numerosos; hipanto não elevado acima do ovário; ovário bilocular, 4-20 óvulos por lóculo. Fruto baga, globosa a elipsóide, de coloração amarela, alaranjada, vermelha, vinácea até preta quando madura, com cálice persistente. Sementes 1-3, embrião tipo eugenióide, cotilédones globosos, carnosos, conferruminados, linha de separação presente entre os cotilédones; eixo hipocótilo-radícula pouco desenvolvido.

Foram registradas dez espécies de Eugenia na área estudada. 
Chave para as espécies de Eugenia da planície alagável do Alto Rio Paraná

1. Flores em dicásio ou solitárias

2. Flores em dicásio, raramente solitárias; folhas densamente velutinas na face abaxial; profilos lineares, densamente velutinos; fruto velutino 6. E. pyriformis

2. Flores solitárias; folhas pubérulas na face abaxial; profilos ovados, glabrescentes; fruto glabro 4. E. klappenbachiana

1. Flores em racemos

3. Eixo da inflorescência (3-) 10-45 mm compr.

4. Folhas limbinérveas; ovário com 8-10 óvulos por lóculo; profilos de ápice agudo; sépalas glabras 1. E. egensis

4. Folhas duplolimbinérveas; ovário com 4 óvulos por lóculo; profilos de ápice obtuso; sépalas pilosas

5. Lâmina foliar 20-40×10-20 mm; nervuras secundárias pouco evidentes; racemos de 5-10 flores, freqüentemente mais longos do que as folhas

5. E. moraviana

5. Lâmina foliar 40-120×20-50 mm; nervuras secundárias bastante evidentes na face abaxial; racemos (5-)6(-8) flores, freqüentemente mais curtos do que as folhas

2. E. florida

3. Eixo da inflorescência reduzido, 1-2 mm compr.

6. Racemos auxotélicos; frutos costados; profilos caducos

7. Folhas ovadas, membranáceas, ápice agudo a acuminado; frutos glabros 10. E. uniflora

7. Folhas oblongas, cartáceas, ápice retuso, às vezes agudo; frutos pilosos 9. E. sulcata

6. Racemos simples; frutos lisos; profilos persistentes

8. Racemos não umbeliformes; flores 4; sépalas de ápice agudo, pubescentes

8. E. repanda

8. Racemos umbeliformes; flores freqüentemente mais de 4; sépalas de ápice obtuso, glabras

9. Folhas ovadas, às vezes elípticas, ápice agudo a curtamente acuminado, base obtusa a aguda, nervura central adaxialmente sulcada, margem cartilagínea

3. E. hyemalis

9. Folhas elípticas, às vezes oblongas, ápice curto a longamente acuminado, base freqüentemente cuneada, nervura central adaxialmente plana, margem estreitocartilagínea

7. E. ramboi
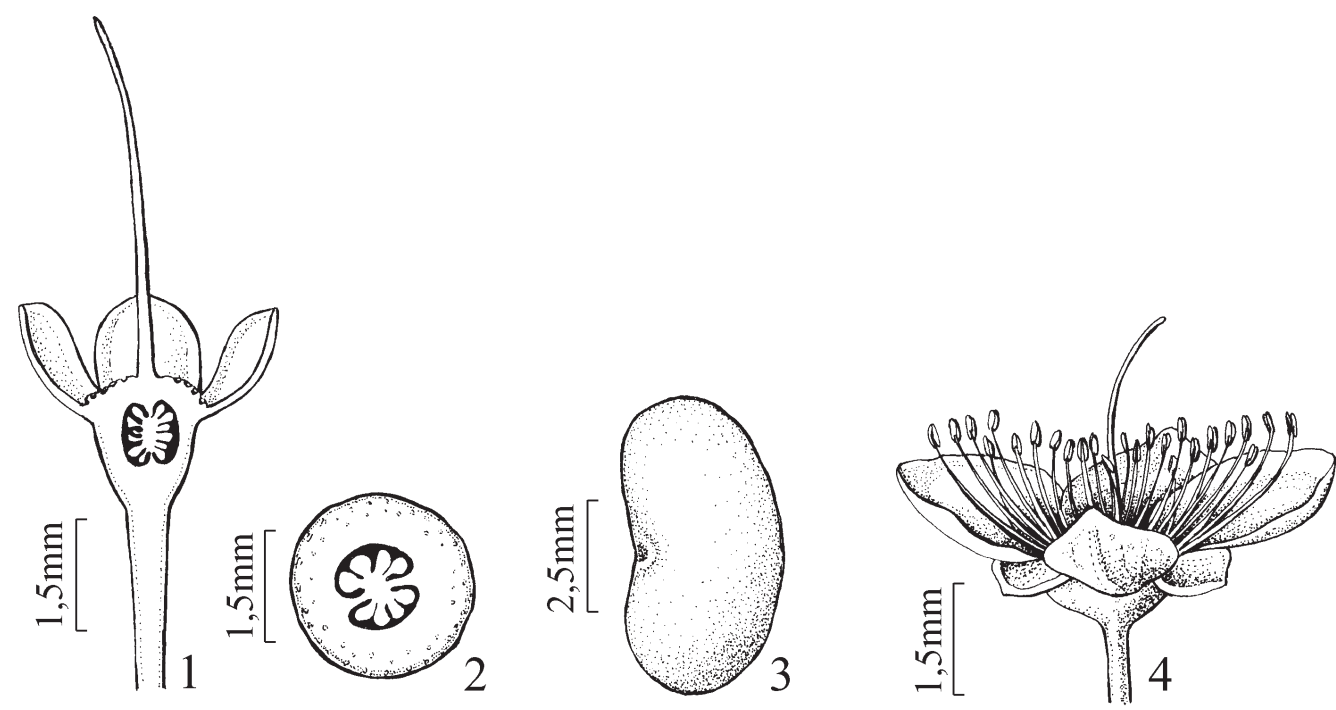

Figuras 1-4. Características morfológicas de Eugenia (Eugenia hyemalis Cambess.). 1. Flor em corte longitudinal. 2. Ovário em corte transversal. 3. Embrião. 4. Flor (M.B. Romagnolo 305). 
1. Eugenia egensis DC., Prodromus 3: 281.1828.

Fig. 5-12

Nome popular: cambuí.

Arbusto a arvoreta, ca. 2-3 m alt. Ramos glabros, esfoliantes em película pálida e delicada, acinzentados a prateados, os mais jovens comprimidos lateralmente, avermelhados no material fresco, enegrescidos no material herborizado. Folhas com lâminas 55-100× 10-35 mm, razão foliar 2,5-5,0, elípticas a oblongas, subcoriáceas, discolores, glabras, pontos translúcidos mais evidentes abaxialmente, limbinérveas, base cuneada, ápice agudo a acuminado, margem estreitocartilagínea, pouco revoluta na base; nervura central adaxialmente sulcada, abaxialmente proeminente; nervuras secundárias 10-12 pares, mais evidentes na face abaxial, ângulo de divergência $60^{\circ}-65^{\circ}$; nervuras marginais até $2 \mathrm{~mm}$ da borda; pecíolos 4-6 $\mathrm{mm}$ compr., adaxialmente sulcados, pilosos a glabros, lenticelas excepcionalmente presentes, transversais. Flores (2-)4-10, em racemos axilares; eixo (3-) 10-20 mm compr., piloso; ferofilos ovados, pardacentos, glabros; antopódio 8-20 mm compr., glabro; profilos persistentes, ca. 1,2×1,2 mm, glabrescentes em ambas as faces, ovados, ápice agudo, margens ciliadas; botões florais 4,5-5,0 mm compr., globosos; sépalas desiguais, 2 ca. $1,7 \times 1,7 \mathrm{~mm}, 2$ ca. $1,2 \times 1,2 \mathrm{~mm}$, ovadas, ápice obtuso, glabras; pétalas ca. $5,0 \times 4,0 \mathrm{~mm}$; disco estaminal glabro, subquadrangular; estames 3,5-6,5 mm compr.; ovário 8-10 óvulos/lóculo, glabro; estilete 7,0-7,5 mm compr., glabro. Frutos globosos a elípticos, 6-10×6-8 mm, alaranjados a avermelhados quando maduros.

Material selecionado: BRASIL. Mato Grosso do Sul: Jateí, rio Ivinheima, 24/VIII/1999, M.B. Romagnolo 179 (HUEM); Taquaruçu, canal Corutuba, 23/VII/1999, M.B. Romagnolo 341 (HUEM); canal Poitã, 25/XI/1999, M.B. Romagnolo 435 (HUEM). Paraná: Porto Rico, rio Paraná, 23/VIII/1999, M.B.Romagnolo 353 (HUEM); canal Cortado, 19/VII/1994, P.M. Silva 99 (HUEM); ilha Carioca, 31/V/2001, M.B.Romagnolo 715 (HUEM); ilha Mutum, 21/X/1995, M.B. Romagnolo 239 (HUEM).

Foram observadas flores em abril e de junho a outubro, e frutos em março e de agosto a dezembro. Pott \& Pott (1994) observaram esses mesmos períodos de reprodução no Pantanal.

Alguns representantes de Eugenia egensis apresentaram inflorescências com eixo de até $20 \mathrm{~mm}$ de comprimento, portanto, mais longo do que o citado por Bernardi (1985) para as espécies do Paraguai, que foi de 2-3 mm.
Apresenta ampla distribuição na área estudada, sendo encontrada mais comumente nos remanescentes dos diques marginais dos canais Cortado (Paraná), Corutuba e Poitã (Mato Grosso do Sul), e das diversas ilhas. Para o Estado do Paraná e áreas limítrofes de sua porção ocidental, sua ocorrência foi registrada anteriormente apenas para a margem direita do rio Paraná, por Romagnolo \& Souza (2000). É abundante na vegetação ripária inundável do Pantanal, assim como do rio Paraguai e de seus afluentes, inclusive no Paraguai, em locais de solo argiloso (Bernardi 1985; Pott \& Pott 1994). Segundo Bernardi (1985), essa espécie ocorre desde as Guianas até a Bolívia e a Argentina.

2. Eugenia florida DC., Prodromus 3: 283. 1828.

Fig. 13-18

Nomes populares: guamirim, pitanga.

Arbusto a arvoreta, ca. 3-7 m alt. Ramos glabros a mais raramente pilosos, esfoliantes, marromacinzentados, freqüentemente prateados, lenticelados, os mais jovens, comprimidos lateralmente. Folhas com lâminas 40-120×20-50 mm, razão foliar 2,0-2,8, elípticas a ovadas, subcoriáceas, glabras, discolores, face adaxial verde-acinzentada a castanho-clara, pontos translúcidos evidentes abaxialmente, duplolimbinérveas, base cuneada, ápice agudo a curtamente acuminado, margem freqüentemente revoluta; nervura central adaxialmente sulcada, com tricomas hialinos esparsamente distribuídos, abaxialmente proeminente, pontos translúcidos esparsos; nervuras secundárias 812 pares, mais evidentes na face abaxial, ângulo de divergência $40^{\circ}-50^{\circ}$; nervuras marginais ca. $3 \mathrm{~mm}$ da borda, nítidas na metade superior; nervuras intramarginais até $1,5 \mathrm{~mm}$ da borda, formadas pelo primeiro par basal de nervura secundária, não confluentes com as demais, correndo paralelo à borda; pecíolos 5-7 mm compr., adaxialmente sulcados, pubérulos, com pontuações translúcidas, freqüentemente com lenticelas transversais, escurecidos no material herborizado. Flores (5-)6(-8), em racemos axilares; eixo 20-30 mm compr., pubérulo; ferofilos $1,2 \times 1,5 \mathrm{~mm}$, glabrescentes em ambas as faces, ovados, ápice agudo, margens densamente ciliadas; antopódio 3-5 mm compr., pubérulo; profilos persistentes, ca. $1,2 \times 1,5 \mathrm{~mm}$, glabrescentes em ambas as faces, ovados, ápice obtuso, margens densamente ciliadas; botões florais 4-6 mm compr., globosos; sépalas desiguais, 2 ca. $2,3 \times 1,8 \mathrm{~mm}, 2$ ca. $1,2 \times 1,8 \mathrm{~mm}$, ovadas, ápice obtuso, pilosas; pétalas ca. $5,5 \times 3,5 \mathrm{~mm}$; disco estaminal 


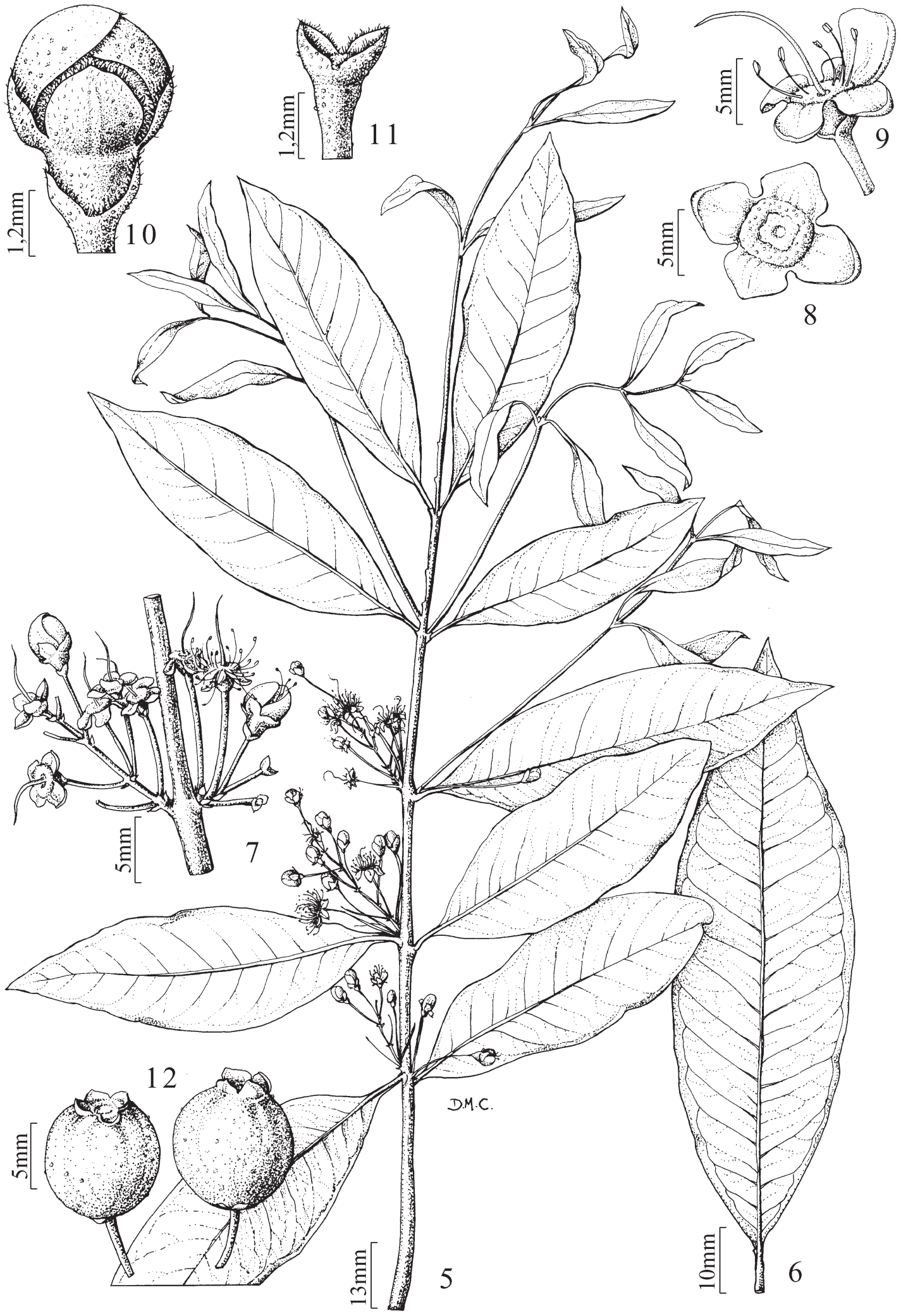

Figuras 5-12. Eugenia egensis DC. 5. Ramo com inflorescência. 6. Folha. 7. Inflorescência. 8. Disco estaminal e sépalas. 9. Disco estaminal. 10. Botão floral. 11. Profilos. 12. Frutos (M.B. Romagnolo 644). 


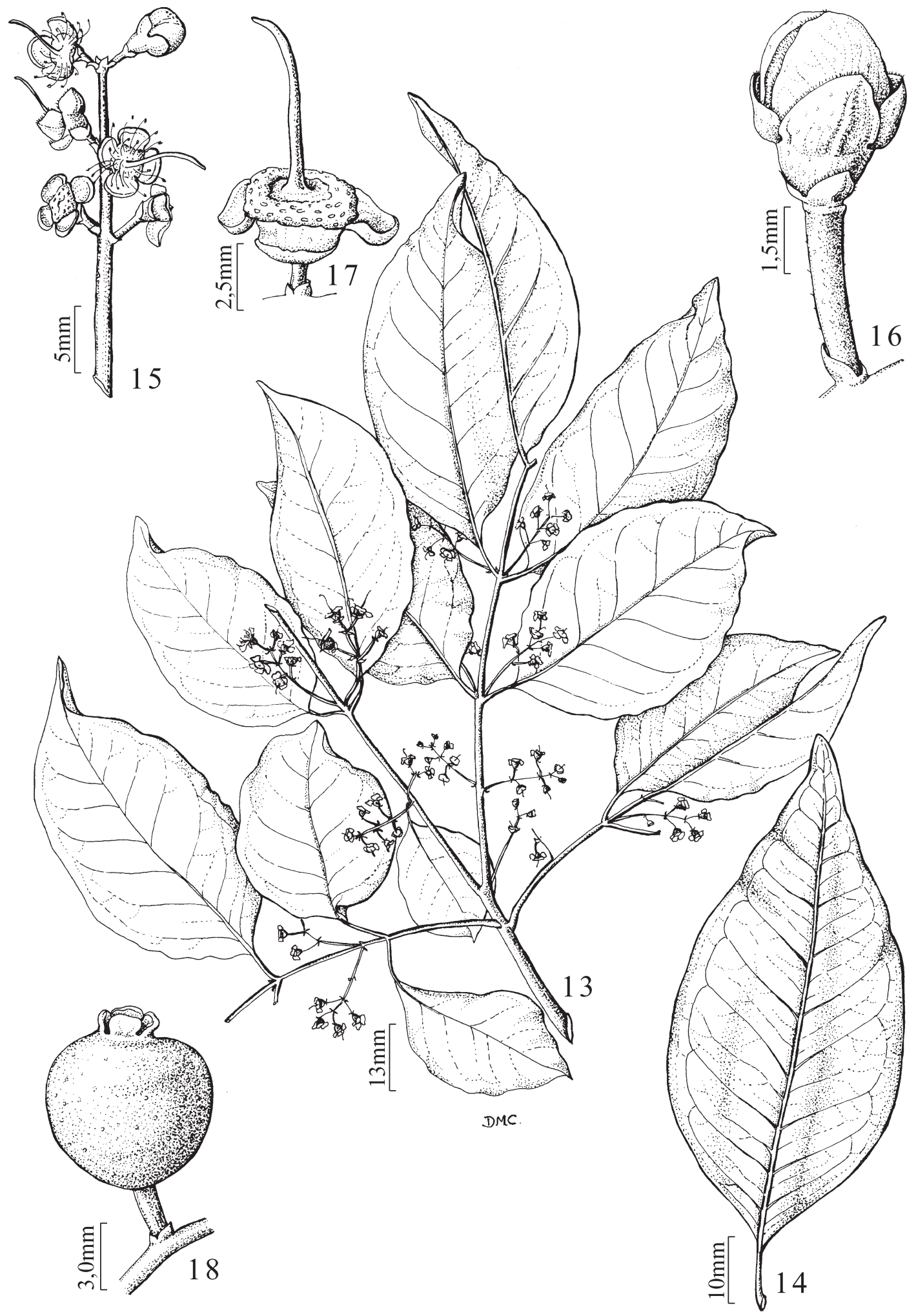

Figuras 13-18. Eugenia florida DC. 13. Ramo com inflorescência. 14. Folha. 15. Inflorescência. 16. Botão floral. 17. Disco estaminal. 18. Fruto (M.B. Romagnolo 424). 
glabro, subquadrangular; estames 3,5-5,0 mm compr.; ovário 4 óvulos/lóculo, glabro; estilete 4,5-5,5 mm compr., glabro. Frutos globosos, 10-13 mm diâm., vermelho-escuros a pretos quando maduros.

Material selecionado: BRASIL. Mato Grosso do Sul: Jateí, rio Ivinheima, 18/IX/1994, M.E. Previdello 81 (HUEM); Taquaruçu, rio Baía, 15/XII/1994, M.C. Souza 837 (HUEM); canal Corutuba, 23/VII/1999, M.B. Romagnolo 347 (HUEM); canal Poitã, 20/IX/1992, M.C. Souza 833 (HUEM); rio Paraná, 18/X/1994, M.E. Previdello 75 (HUEM). Paraná: Porto Rico, córrego Caracu, 24/IX/2000, M.B. Romagnolo 574 (HUEM); ilha Mutum, 19/X/1994, M.E. Previdello 77 (HUEM); São Pedro do Paraná, rio Paraná, 16/X/1999, M.B. Romagnolo 424 (HUEM); ribeirão São Pedro, 14/XII/2001, M.B. Romagnolo 336 (HUEM).

Foram observadas flores de agosto a outubro, com predomínio em setembro, e frutos de setembro a dezembro.

Eugenia florida apresenta folhas membranáceas e avermelhadas quando jovens, tornando-se subcoriáceas quando adultas, sendo bastante variáveis quanto ao tamanho, o que pode ser observado em um mesmo indivíduo. Eugenia florida assemelha-se a E. moraviana, ambas apresentando racemos longos, o que as diferencia das demais espécies da área estudada. Eugenia florida, no entanto, possui folhas mais largas, de ápice curtamente acuminado e nervuras secundárias mais evidentes, e mais longas do que os racemos. As flores e os frutos, entretanto, não oferecem atributos distintivos. Baseando-se nessa dificuldade, Priori et al. (2002) realizaram um estudo de polimorfismo molecular, evidenciado com RAPD (Random Amplified Polymorphic DNA), para verificar a diversidade genética entre populações de E. florida e E. moraviana na mesma região deste estudo, concluindo que as populações de E. florida e E. moraviana são diferentes.

É uma espécie de ampla distribuição na área de estudo, sendo, entretanto, mais abundante nas florestas dos diques marginais das ilhas e dos canais Baía, Corutuba e Poitã. De acordo com Lorenzi (1992), é uma espécie de vegetação secundária, indiferente às condições de umidade do solo, sendo freqüentemente encontrada no interior das matas e nos fundos de vale, onde o solo é profundo e fértil, e recomendada para paisagismo e reflorestamento. Seus frutos são apreciados por aves que disseminam as sementes. Segundo McVaugh (1958), é uma das espécies de Eugenia de mais ampla distribuição na
América do Sul, estendendo-se desde a Colômbia até a Bolívia, e desde a Guiana até o sul do Brasil, desenvolvendo-se nas mais variadas amplitudes ecológicas.

3. Eugenia hyemalis Cambess., Flora Brasiliae Meridionalis 2:259. 1830.

Fig. 19-26

Nomes populares: guamirim-de-folha-miúda, guamirim.

Arbusto a arvoreta, ca. 3-6 m alt. Ramos glabros a mais raramente pilosos, esfoliantes em placas longitudinais irregulares, marrom-acinzentados, raramente prateados, lenticelados, os mais jovens comprimidos lateralmente na região dos nós; tricomas simples, aglomerados na região dos nós. Folhas com lâminas 35-70×15-30 mm, razão foliar 1,8-2,7, ovadas, às vezes elípticas, coriáceas, concolores a discolores, glabras, excepcionalmente com tricomas reduzidos às nervuras centrais, pontos translúcidos mais evidentes abaxialmente, limbinérveas, base obtusa a aguda, ápice de agudo a curtamente acuminado, margem lisa a ondulada, cartilagínea, freqüentemente revoluta; nervura central adaxialmente sulcada, abaxialmente proeminente; nervuras secundárias 8-12 pares, mais evidentes na face abaxial, ângulo de divergência $50^{\circ}-65^{\circ}$; nervuras marginais até $3 \mathrm{~mm}$ da borda; pecíolos 2-3 mm compr., adaxialmente sulcados, glabros a pilosos, freqüentemente muito rugosos, com lenticelas transversais, escuros a pardacentos no material herborizado. Flores (2-)3-8, em racemos umbeliformes, axilares, extra-axilares ou terminais, freqüentemente em ramos desfolhados; eixo muito reduzido a ausente; ferofilos triangulares, pilosos em ambas as faces, margens ciliadas; antopódio 5-10 mm compr., glabro, brilhante; profilos persistentes, ca. $1,2 \times 0,8 \mathrm{~mm}$, glabrescentes em ambas a faces, ovados, ápice agudo, margens ciliadas; botões florais $4-6 \mathrm{~mm}$ compr., globosos; sépalas desiguais, 2 ca. $2,3 \times 2,0 \mathrm{~mm}, 2$ ca.1,7×1,8 mm, ovadas, ápice obtuso, glabras; pétalas ca. $6,0 \times 4,5 \mathrm{~mm}$; disco estaminal glabro, circular; estames 3-6 mm compr.; ovário 6-9 óvulos/lóculo, glabro; estilete 6-7 mm compr., glabro. Frutos oblongos, 8-11×5-7 $\mathrm{mm}$, vináceos a pretos quando maduros.

Material selecionado: BRASIL. Mato Grosso do Sul: Bataiporã, rio Baía, 25/IX/2000, M.B. Romagnolo 583 (HUEM); Jateí, rio Ivinheima, 24/VIII/1999, M.B. Romagnolo 382 (HUEM); rio Baía, 14/VI/2000, M.B. Romagnolo 501 (HUEM); canal Corutuba, 23/VII/1999, M.B. Romagnolo 342 (HUEM); canal Poitã, 16/VI/2000, M.B. Romagnolo 


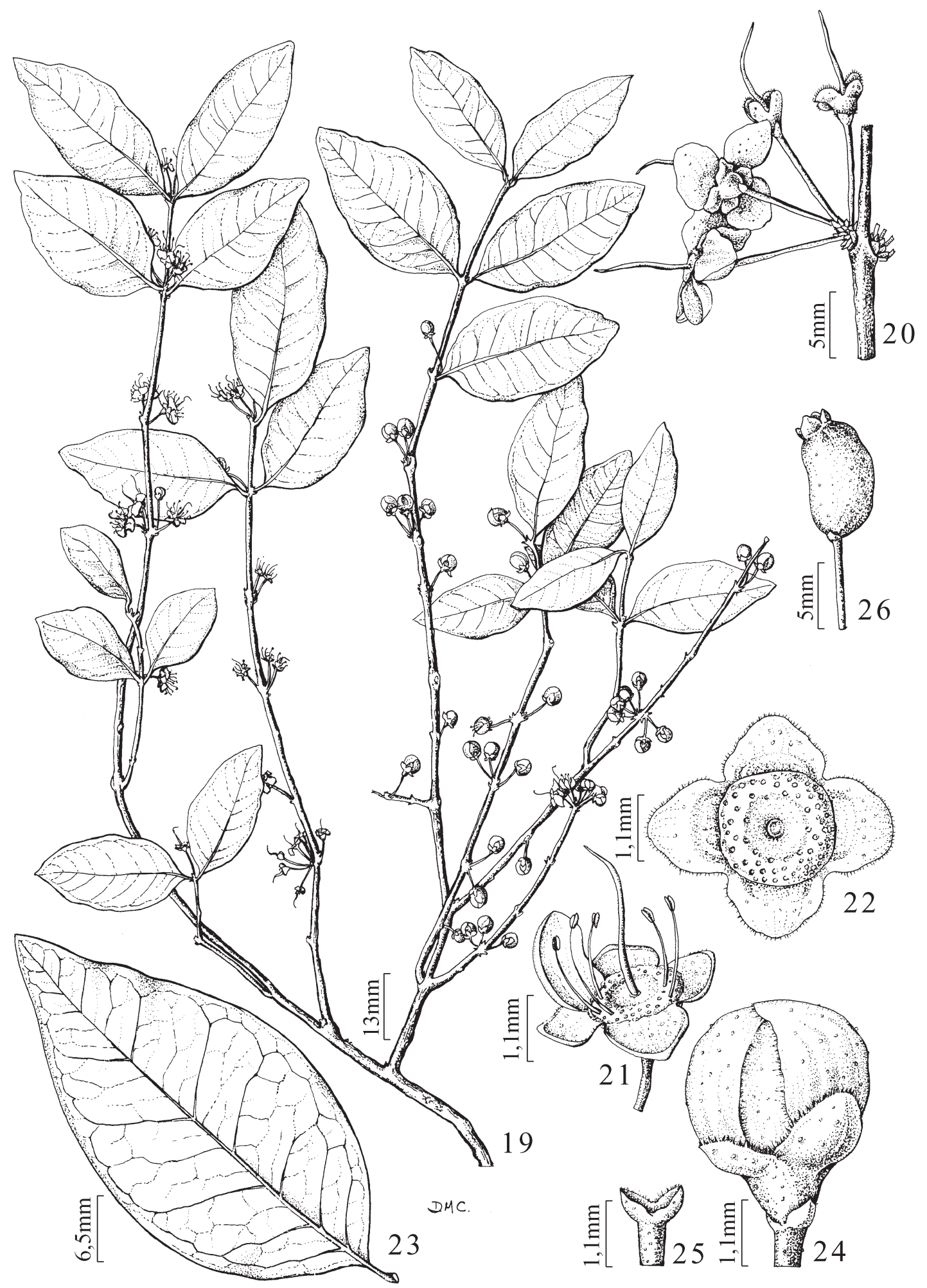

Figuras 19-26. Eugenia hyemalis Cambess. 19. Ramo com inflorescência. 20. Inflorescência. 21. Disco estaminal. 22. Disco estaminal e sépalas. 23. Folha. 24. Botão floral. 25. Profilos. 26. Fruto (M.B. Romagnolo 305). 
523 (HUEM); rio Ivinheima, 16/VI/2000, M.B. Romagnolo 514 (HUEM). Paraná: Porto Rico, rio Paraná, 23/VII/1999, M.B. Romagnolo 351 (HUEM); ilha Cajá, 17/IV/1994, M.E. Previdelo (HUEM); ilha Carioca, 31/V/2001, M.B. Romagnolo 714 (HUEM); ilha Japonesa, 31/V/2001, M.B. Romagnolo 711 (HUEM); ilha das Pombas, 16/VI/2000, M.B. Romagnolo 551 (HUEM); ilha Porto Rico, 17/V/1994, M.B. Romagnolo 238 (HUEM); São Pedro do Paraná, rio Paraná, 16/X/1999, M.B. Romagnolo 426 (HUEM); ribeirão São Pedro, 24/VIII/2001, M.B. Romagnolo 305 (HUEM).

Foram observadas flores de março a agosto, com predomínio em junho, e frutos de abril a outubro. $\mathrm{O}$ período reprodutivo observado estende-se por oito meses, sendo comum encontrar indivíduos com botões e/ou flores, e outros com frutos no mesmo período. Soares-Silva (2000), na bacia do rio Tibagi (Paraná), registrou um período de reprodução igual ao da área de estudo.

Eugenia hyemalis apresenta folhas com forma, coloração e pilosidade variadas. Em alguns indivíduos ocorrem lâminas ovadas, de coloração mais escura e tricomas nas nervuras centrais, em oposição a outros, com lâminas elípticas, de coloração mais pálida e nervura central glabra. Difere das demais espécies da área de estudo por apresentar folhas de margens cartilagíneas e sépalas de coloração creme-esverdeada até vinácea, destacando os indivíduos, na paisagem, quando floridos.

É uma espécie de ampla distribuição na área de estudo, sendo encontrada em todos os ambientes visitados. Nos remanescentes florestais pouco perturbados, faz parte do sub-bosque, juntamente com outras espécies de Eugenia e de Rubiaceae. Em áreas muito perturbadas, ocupadas ou não por pastagem, forma densas populações de indivíduos com 2-3 m de altura, bastante ramificados desde a base, que ocorrem agrupados e chegam a florescer e frutificar com a altura de $50 \mathrm{~cm}$. De acordo com Legrand \& Klein (1969) e Bernardi (1985), é encontrada com freqüência nas margens dos rios, em áreas de pastagem e em associações secundárias, não tendo exigências de umidade. Segundo Kawasaki (1989), ocorre nas matas ciliares da Serra do Cipó, no Estado de Minas Gerais, distribuindo-se até o Estado do Rio Grande do Sul, Argentina, Uruguai e Paraguai.

4. Eugenia klappenbachiana Mattos \& D. Legrand, Loefgrenia 67: 26. 1975.

Fig. 27-34
Nome popular: cambuí.

Arvoreta a árvore, ca. 4-12 m alt. Ramos pubescentes a glabros, esfoliantes, pardacentos a cinéreos, lenticelas longitudinais de coloração marrom, os mais jovens comprimidos lateralmente na região dos nós, com tricomas albo-seríceos. Folhas com lâminas 30-75×15-35 mm, razão foliar 1,7-3,4, elípticas a ovadas, membranáceas, glabras a pubérulas, discolores, abaxialmente opacas, pontuações translúcidas densas mais evidentes adaxialmente, limbinérveas, menos freqüentemente duplo-limbinérveas, base obtusa a aguda, ápice agudo a acuminado, margem ciliada, principalmente nas mais jovens; nervura central adaxialmente pouco sulcada, abaxialmente proeminente, pilosa nas folhas mais jovens; nervuras secundárias 10-12 pares, tênues, ângulo de divergência $70^{\circ}-75^{\circ}$; nervuras marginais até $3,0 \mathrm{~mm}$ da borda; pecíolos 3-6 mm compr., adaxialmente sulcados, pilosos, freqüentemente com lenticelas transversais. Flores solitárias, axilares, menos freqüentemente em racemos; ferofilos caducos, densamente seríceos, ovados; antopódio 4-12 mm compr., albo-seríceo; profilos caducos, ca. 1,5×0,8 mm, glabrescentes, ovados, ápice agudo, margens densamente ciliadas; botões florais 4-6 mm compr., obovados; sépalas desiguais, 2 ca. $2,3 \times 2,3 \mathrm{~mm}, 2$ ca. $1,4 \times 2,3 \mathrm{~mm}$, ovadas, ápice obtuso a cordado, pilosas; pétalas ca. $6,5 \times 5,0 \mathrm{~mm}$; disco estaminal albo-seríceo, subquadrangular; estames 3,5-6,0 mm compr., glabros; ovário 4 óvulos/lóculo, densamente albo-seríceo; estilete 6,0-6,5 mm compr., glabro. Frutos obovados, 8-12×6-10 mm, glabros, amarelos a alaranjados quando maduros.

Material selecionado: BRASIL. Mato Grosso do Sul: Bataiporã, rio Baía, 30/IX/2000, M.B. Romagnolo 657 (HUEM); Jateí, rio Ivinheima, 8/XII/1992, M.C. Souza \& S.C. Negreli 16 (HUEM). Paraná: Porto Rico, rio Paraná, 29/IX/2000, M.B. Romagnolo 639 (HUEM).

Foram observadas flores de julho a novembro, e frutos de agosto a dezembro. Difere das demais espécies de Eugenia estudadas por apresentar geralmente flores solitárias e folhas densamente pontuadas.

Apresenta distribuição moderada na área de estudo, sendo encontrada mais comumente no interior de remanescentes florestais pouco perturbados, onde é comum a ocorrência de indivíduos adultos, com cerca de 7-10 m de altura, e de muitos indivíduos jovens nas suas proximidades. Não foi observada sua ocorrência em áreas perturbadas. Não foi registrada por Soares-Silva (2000) na bacia do rio Tibagi (PR). 


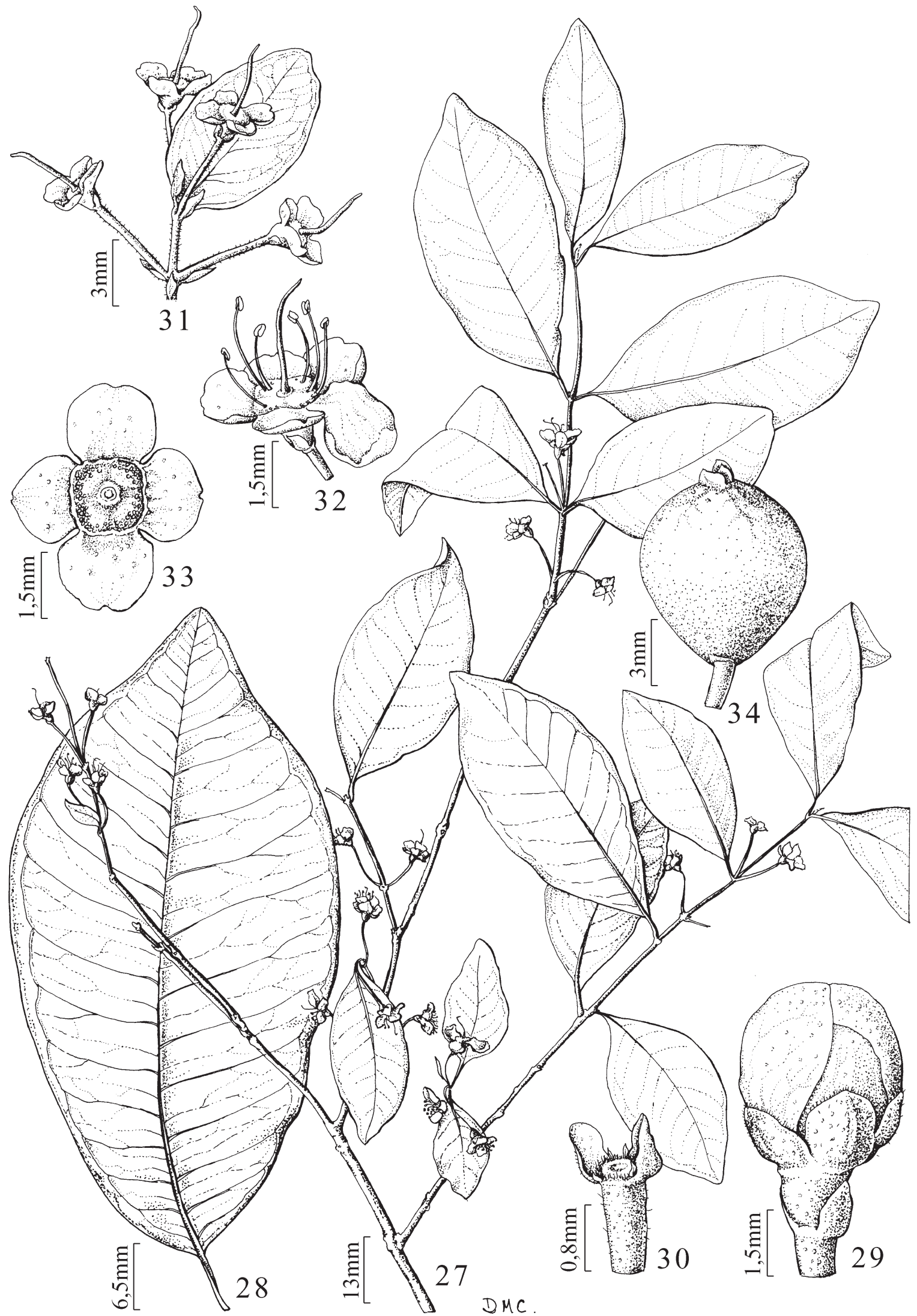

Figuras 27-34. Eugenia klappenbachiana Mattos \& D. Legrand. 27. Ramo com flores. 28. Folha. 29. Botão floral. 30. Profilos. 31. Inflorescência. 32. Disco estaminal. 33. Disco estaminal e sépalas. 34. Fruto (M.B. Romagnolo 589). 
5. Eugenia moraviana O. Berg, Fl. bras. 14(1): 304. 1857.

Fig. 35-41

Nomes populares: cambuí, cambuim.

Arbusto a arvoreta, ca. 2-5 m alt. Ramos pubescentes a glabros com a idade, esfoliantes, pardacentos, lenticelados, os mais jovens comprimidos lateralmente, pilosos. Folhas com lâminas 20-40× 10-20 mm, razão foliar 1,8-2,4, elípticas a ovadas, cartáceas, concolores a discolores, adaxialmente argênteas, glabrescentes, duplolimbinérveas, base cuneada a estreitamente cuneada, ápice agudo a longamente acuminado, margem esparsamente ciliada; nervura central adaxialmente sulcada, pubérula, abaxialmente proeminente; nervuras secundárias 8-10 pares, tênues, ângulo de divergência $45^{\circ}-55^{\circ}$; nervuras marginais até $3 \mathrm{~mm}$ da borda; nervuras intramarginais até $1 \mathrm{~mm}$ da borda; pecíolos 3-6 $\mathrm{mm}$ compr., adaxialmente sulcados, pilosos, freqüentemente com lenticelas transversais. Flores 5-10, raramente menos, em racemos axilares; eixo (15-)20-45 mm compr., pubérulo; ferofilos freqüentemente caducos, abaxialmente pubérulos, adaxialmente pilosos, ovados, ápice agudo, margens densamente longo-ciliadas; antopódio 5-10 $\mathrm{mm}$ compr., pubérulo; profilos persistentes, ca. 1,2×1,0 mm, abaxialmente glabrescentes, adaxialmente pilosos, ovados, ápice obtuso, margens densamente ciliadas; botões florais 3-4 mm compr., globosos; sépalas desiguais, 2 ca. 1,4×1,2 mm, 2 ca. $0,8 \times 1,2 \mathrm{~mm}$, ovadas, ápice obtuso, pilosas; pétalas ca. 3,0×2,3 $\mathrm{mm}$; disco estaminal glabro, circular; estames 2-3 mm compr., glabros; ovário 4 óvulos/ lóculos, glabro; estilete 3,5-4,0 mm compr., glabro. Frutos globosos, 5-8 mm diâm., vermelho-escuros a pretos quando maduros.

Material selecionado: BRASIL. Mato Grosso do Sul: Bataiporã, rio Baía, 25/IX/2000, M.B. Romagnolo 591 (HUEM); Jateí, rio Ivinheima, 18/X/1992, M.C. Souza 507 (HUEM); Taquaruçu, canal Poitã, 16/XI/1994, M.C. Souza 574 (HUEM), rio Paraná, 27/IX/1995, M.C. Souza \& J.Cinslinski 4 (HUEM). Paraná: Porto Rico, rio Paraná, 23/VIII/1999, M.B. Romagnolo 356 (HUEM); canal Cortado, 19/IX/1992, M.C. Souza 838 (HUEM); córrego Caracu, 24/IX/2000, M.B. Romagnolo 573 (HUEM); ilha Mutum, 26/IX/2000, M.B. Romagnolo 601 (HUEM); ilha Porto Rico, 26/IX/2000, M.B. Romagnolo 602 (HUEM); ribeirão São Pedro, 28/IX/2000, M.B. Romagnolo 632 (HUEM).

Foram observadas flores de agosto a outubro, com predomínio em agosto, e frutos de setembro a novembro, predominando em setembro. Esse período de reprodução também foi registrado por Kausel (1966) e Rotman (1995) para a flora da Argentina.

Eugenia moraviana, juntamente com E. florida, difere das demais espécies da área por apresentar racemos longos. Suas folhas apresentam coloração argêntea característica, no material herborizado.

Apresenta ampla distribuição na área de estudo, ocorrendo mais comumente no sub-bosque dos remanescentes de mata pouco perturbados. De acordo com Rotman (1995), distribui-se no sul do Brasil, Bolívia, Paraguai até o sul da Argentina. Trata-se de uma espécie seletiva higrófita e exclusiva de matas ripárias, sendo muito freqüente na região chaqueana do Paraguai e da Argentina (Legrand \& Klein 1969).

6. Eugenia pyriformis Cambess., Flora Brasiliae Meridionalis 2: 336. 1832.

Fig. $42-49$

Nomes populares: uvaia, uvaieira, uvalha.

Arbusto a arvoreta, ca. 3-5 m alt. Ramos pubescentes a glabrescentes com a idade, esfoliantes, de coloração marrom-avermelhada, os mais jovens comprimidos lateralmente, albo-seríceos. Folhas com lâminas 15-75×5-20 mm, razão foliar 2,0-5,5, elípticas a oblongas, cartáceas, concolores a discolores, face adaxial de verde-escura a pardacenta, esparsamente velutina, glabrescente na maturidade, face abaxial verde-clara a argêntea, densamente velutina, pontuações translúcidas densas, ocultas pelo indumento, duplolimbinérveas, base obtusa, ápice agudo, margem ciliada, pouco revoluta; nervura central adaxialmente sulcada na metade inferior, abaxialmente proeminente, com tricomas hialinos densos; nervuras secundárias 8-16 pares, mais evidentes na face abaxial, ângulo de divergência $55^{\circ}-60^{\circ}$; nervuras intersecundárias com diâmetro semelhante ao das secundárias, pouco ramificadas; nervuras marginais até $1 \mathrm{~mm}$ da borda; nervuras intramarginais inconspícuas; pecíolos 3-4 mm compr., sulcados adaxialmente, pilosos. Flores 3, em dicásios, raramente solitárias, axilares, velutinas; ferofilos não observados; antopódio 3-5 mm compr., piloso, flor central séssil; profilos caducos na antese, ca. $2,0 \times 0,3 \mathrm{~mm}$, densamente velutinos em ambas as faces, lineares, ápice agudo; botões florais 4-5 mm compr., piriformes, densamente velutinos; sépalas desiguais, 2 ca. 2,3×2,3 mm, quadrangulares, 2 ca. $1,8 \times 2,3 \mathrm{~mm}$, ovadas, velutinas em ambas as faces, ápice obtuso; pétalas ca. $5,0 \times 3,5 \mathrm{~mm}$; disco estaminal velutino, quadrangular; estames 3,0-5,0 $\mathrm{mm}$ compr., pubescentes; ovário 4-6 ovúlos/lóculo, densamente 


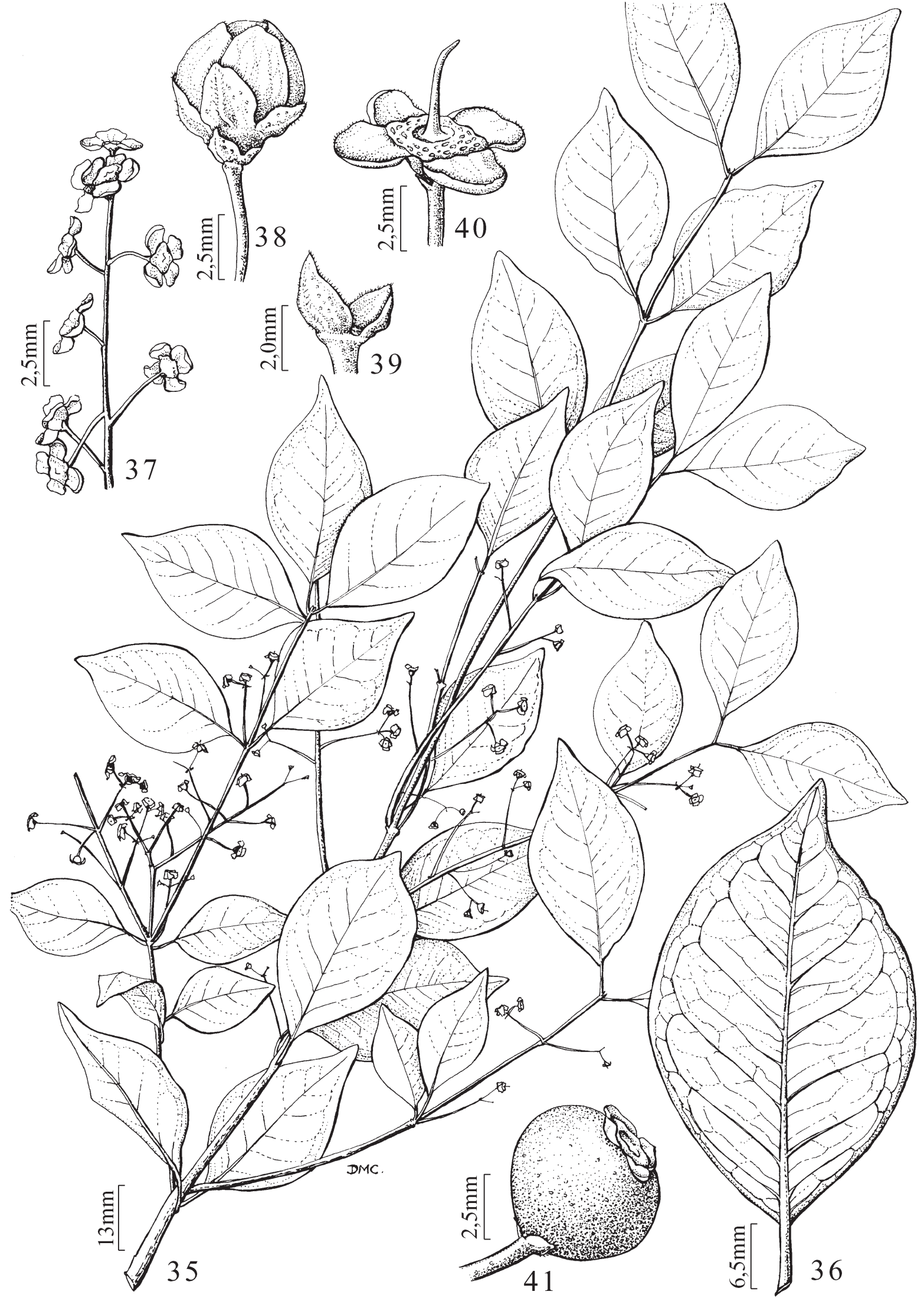

Figuras 35-41. Eugenia moraviana O. Berg. 35. Ramo com inflorescência. 36. Folha. 37. Inflorescência. 38. Botão floral. 39. Profilos. 40. Disco estaminal. 41. Fruto (M.B. Romagnolo 573). 


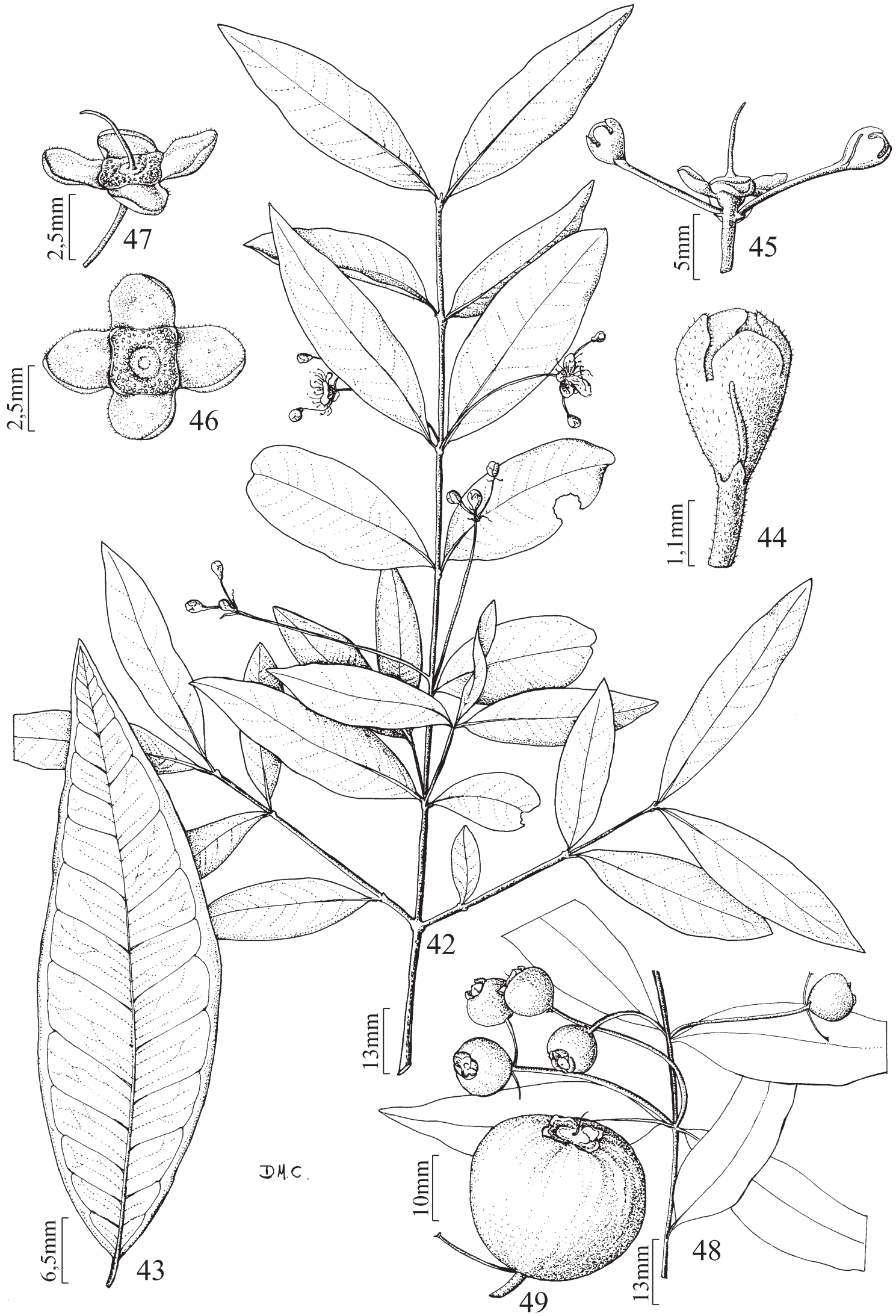

Figuras 42-49. Eugenia pyriformis Cambess. 42. Ramo com inflorescência. 43. Folha. 44. Botão floral. 45. Inflorescência. 46. Disco estaminal e sépalas. 47. Disco estaminal. 48. Ramo com frutos. 49. Fruto (M.B. Romagnolo 537 e 669). 
velutino, lóculos pilosos internamente; estilete 6,0-6,5 mm compr., piloso. Frutos subglobosos, 20-30 mm diâm., velutinos, amarelados ou alaranjados quando maduros.

Material selecionado: BRASIL. Mato Grosso do Sul: Bataiporã, rio Baía, 6/IX/1999, M.B. Romagnolo 403 (HUEM); Jateí, rio Ivinheima, 14/III/2000, M.B. Romagnolo 477 (HUEM); 16/VI/2000, M.B. Romagnolo 537 (HUEM). Paraná: Porto Rico, rio Paraná, 27/IX/2000, M.B. Romagnolo 604 (HUEM); São Pedro do Paraná, ribeirão São Pedro, 28/IX/2000, M.B. Romagnolo 634 (HUEM).

Foram observadas flores em março, julho, setembro e novembro, e frutos em junho. Marchiori \& Sobral (1997), para o Rio Grande do Sul, observaram maior concentração de flores de novembro a dezembro e de maturação dos frutos de janeiro a fevereiro.

Eugenia pyriformis diferencia-se das demais espécies de Eugenia estudadas, por apresentar lâminas foliares elípticas a oblongas, densamente velutinas na face abaxial, principalmente nas mais jovens, e flores em dicásio, raramente solitárias. Na área estudada, distribui-se em vários tipos de ambientes, desde pouco perturbados até em áreas abertas e ocupadas por pastagem, porém, não foi observada em todos os ambientes visitados.

De acordo com Marchiori \& Sobral (1997), é uma espécie nativa da bacia dos rios Paraná e Uruguai. Segundo Legrand \& Klein (1969), sua ocorrência é bastante comum nas formações abertas das florestas semidecíduas de altitude e da bacia do rio Paraná, bem como no sub-bosque das matas abertas de pinhais e nas matas do oeste do Estado de Santa Catarina, onde apresenta ampla e expressiva distribuição. Em algumas regiões, apresenta altura menor e flores solitárias, assemelhando-se a E. uvalha. De acordo com Lorenzi (1992) e Backes \& Irgang (2002), seus frutos são comestíveis, apreciados pelo homem e por pássaros, sendo recomendada para recomposição da vegetação e para paisagismo.

Foi registrada ao longo de toda a bacia do rio Tibagi por Soares-Silva (2000), para as Regiões Sul, Sudeste e Centro-Oeste do Brasil, e também para a Argentina, Paraguai e Uruguai (Legrand 1968; Legrand \& Klein 1969; Bernardi 1985; Rotman 1995; Soares-Silva 2000).

7. Eugenia ramboi D. Legrand, Sellowia 13: 321. 1961.

Nomes populares: batinga-branca, ingabaú.

Arvoreta, ca. de $7 \mathrm{~m}$ alt. Ramos glabros, pouco esfoliantes, castanhos a cinérios, os mais jovens comprimidos lateralmente, pubérulos. Folhas com lâminas 30-60×15-20 mm, razão foliar 1,5-3,0, elípticas, às vezes oblongas, membranáceas, discolores, abaxialmente verde-claras, opacas, adaxialmente verde-escuras, brilhantes, pontuações translúcidas pouco evidentes, glabras, limbinérveas, base freqüentemente cuneada, ápice longamente acuminado, às vezes curtamente acuminado, margem estreitocartilagínea, ondulada, revoluta; nervura central adaxialmente plana, com tricomas curtos, abaxialmente pouco proeminente; nervuras secundárias 8-12 pares, evidentes, ângulo de divergência $55^{\circ}-65^{\circ}$; nervuras intersecundárias visíveis; nervura marginal até $2,0 \mathrm{~mm}$ da borda; pecíolos 4-5 mm compr., canaliculados, lenticelados, glabros. Flores e frutos não observados.

Material examinado: BRASIL. Mato Grosso do Sul: Jateí, rio Ivinheima, 4/III/2002, M.B. Romagnolo 503 (HUEM). Paraná: São Pedro do Paraná, ribeirão São Pedro, 24/VIII/2001, M.B. Romagnolo 307 (HUEM).

Soares-Silva (2000) registrou, na bacia do rio Tibagi (Estado do Paraná), flores nos meses de abril e de outubro a dezembro, e frutos em março.

Eugenia ramboi caracteriza-se por apresentar folhas elípticas, às vezes oblongas, de ápice longamente acuminado que, quando amassadas, apresentam cheiro de canela (Lauraceae), conforme já assinalado por Soares-Silva (2000).

Apresenta distribuição restrita na área de estudo, tendo sido registrada apenas para a vegetação do ribeirão São Pedro e para um remanescente florestal do rio Ivinhema. Segundo Legrand \& Klein (1969), ocorre da Região Sul do Brasil até o norte do Paraguai, é indiferente às condições físicas dos solos e desenvolve-se tanto em terrenos úmidos quanto secos.

8. Eugenia repanda O. Berg, F1. bras. 14(1): 304. 1857.

Fig. 50-57

Nomes populares: pitanguinha, camboim, nhangapiri-preto.

Arbusto a arvoreta, ca. 1,0-5,0 m alt. Ramos glabros, pouco esfoliantes, pardacentos a cinéreos, os mais jovens comprimidos lateralmente, com tricomas hialinos. Folhas com lâminas 20-60×10-20 mm, razão foliar 1,5-3,5, elípticas a estreitamente elípticas, membranáceas, concolores a discolores, pontuações translúcidas densas, mais evidentes adaxialmente, glabras a pubescentes quando jovens, limbinérveas, base cuneada a estreitamente cuneada, ápice acuminado, margem lisa a ondulada, pouco involuta; 


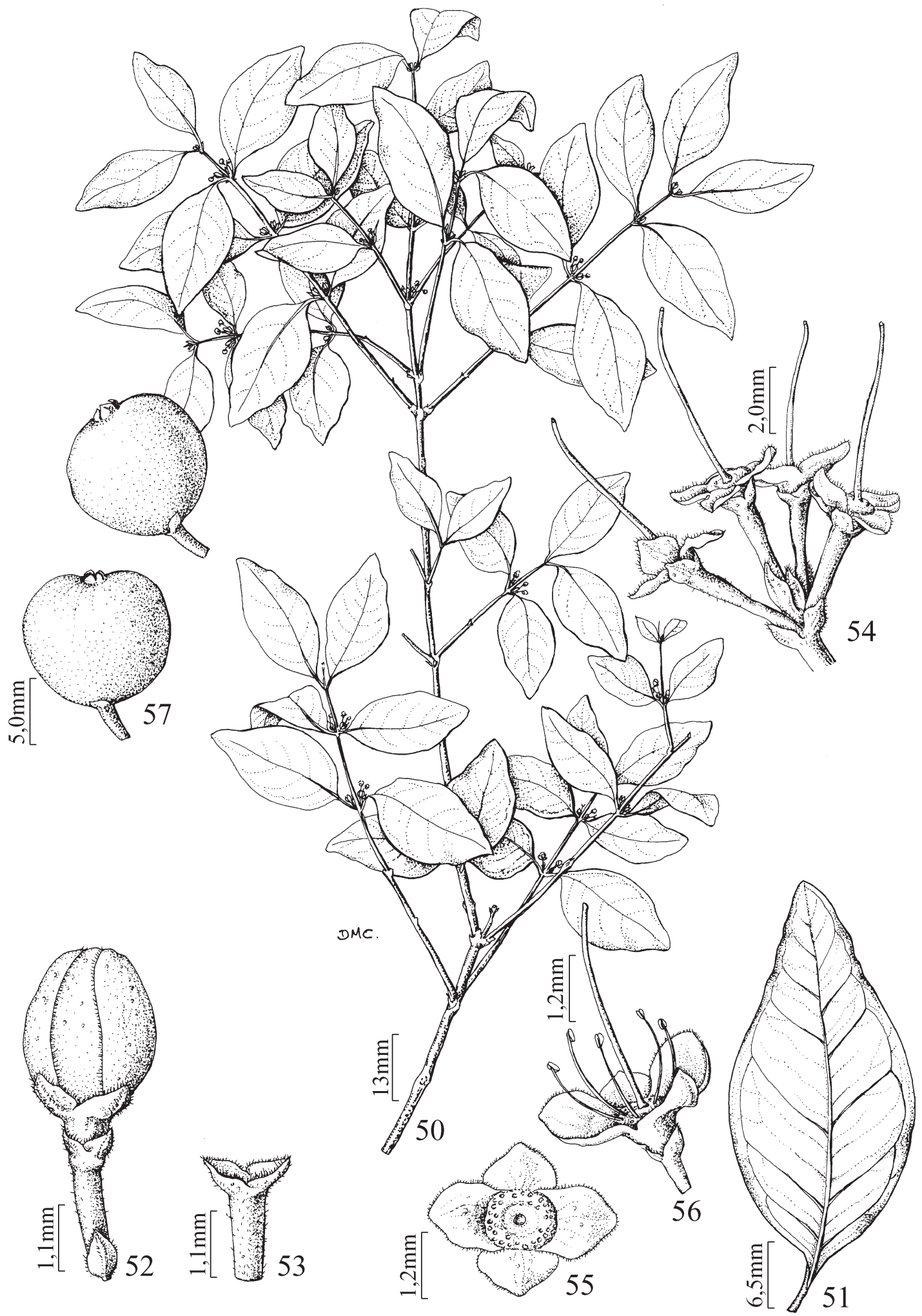

Figuras 50-57. Eugenia repanda O.Berg. 50. Ramo com inflorescência. 51. Folha. 52. Botão floral. 53. Profilos. 54. Inflorescência. 55. Disco estaminal e sépalas. 56. Disco estaminal e estames. 57. Frutos (M.B. Romagnolo 578). 
nervura central com tricomas hialinos, adpressos, adaxialmente sulcada, principalmente na metade inferior, abaxialmente pouco proeminente; nervuras secundárias 7-10 pares, tênues, quase invisíveis adaxialmente, ângulo de divergência $55^{\circ}-60^{\circ}$; nervuras intersecundárias excepcionalmente perceptíveis; nervuras marginais até $1,0 \mathrm{~mm}$ da borda; pecíolos 3-6 mm compr., glabros. Flores 4, em racemos axilares e terminais; eixo 1-2 mm compr.; ferofilos ovados, velutinos em ambas as faces; antopódio ca. 2,5 mm compr., pubescente; profilos persistentes, ca. 1,0×1,0 mm, ovados, ápice acuminado por fechamento das bordas para a face adaxial, margens densamente ciliadas, tricomas hialinos dispostos ao longo da nervura central; botões florais 3-4 mm compr., obovados; sépalas subiguais, 2 ca. 1,7×1,1 mm, 2 ca. $1,1 \times 1,1 \mathrm{~mm}$, ovadas, ápice agudo, pubescentes; pétalas ca. $3,5 \times 2,5 \mathrm{~mm}$; disco estaminal glabro, circular; estames 3-5 mm compr., glabros; ovário 8-10 óvulos/ lóculo, glabro, recoberto pelos profilos; estilete 4,5-6,5 mm compr., glabro. Frutos globosos, 4-6 mm diâm., alaranjados a avermelhados quando maduros.

Material selecionado: BRASIL. Mato Grosso do Sul: Bataiporã, rio Baía, 29/XI/1999, M.B. Romagnolo 449 (HUEM); Jateí, rio Ivinheima, 14/XII/2001, M.B. Romagnolo 363 (HUEM). Paraná: Porto Rico, rio Paraná, 16/X/1999, M.B. Romagnolo 420 (HUEM); córrego Caracu, 24/IX/2000, M.B. Romagnolo 578 (HUEM); ilha Porto Rico, 21/I/2000, M.B. Romagnolo 454 (HUEM); São Pedro do Paraná, rio Paraná, 16/X/1999, M.B. Romagnolo 425 (HUEM); ribeirão São Pedro, 14/II/2001, M.B. Romagnolo 708 (HUEM); Marilena, rio Paraná, 1/II/2001, M.B. Romagnolo 705 (HUEM).

Foram observadas flores de agosto a fevereiro, e frutos em setembro, dezembro e janeiro. O período reprodutivo observado estendeu-se por nove meses, sendo comum encontrar, no mesmo período, indivíduos com botões e/ou flores, e outros com frutos.

Os indivíduos de Eugenia repanda encontrados no interior dos remanescentes florestais ou em áreas abertas apresentaram altura de aproximadamente 5,0 $\mathrm{m}$ e copa bastante ramificada, enquanto que os encontrados sobre os paredões de arenito da margem esquerda do rio Paraná, alcançaram de 1,0 a 1,5 m de altura.

Apresenta ampla distribuição na área de estudo, tendo sido observada em todos os ambientes visitados, sendo muito comum nos paredões de arenito da margem esquerda do rio Paraná. Distribui-se do Rio de Janeiro até o Rio Grande do Sul, Paraguai, Argentina e Uruguai (Kausel 1966; Legrand \& Klein 1969; Rotman 1995).

9. Eugenia sulcata Spring. ex Mart., F1. bras. 20(2): 85. 1837.

Nome popular: pitanga.

Arvoreta, ca. 3,0 m alt. Ramos pubérulos, esfoliantes, pardacentos, os mais jovens comprimidos lateralmente. Folhas com lâminas 15-45×10-15 mm, razão foliar 1,2-2,0, oblongas, cartáceas, concolores a discolores, glabras, pontos translúcidos mais evidentes adaxialmente, limbinérveas, base obtusa a aguda, ápice retuso, às vezes agudo, margem pouco revoluta; nervura central adaxialmente sulcada, abaxialmente proeminente, pilosa; nervuras secundárias 6-8 pares, adaxialmente sulcadas, ângulo de divergência $45^{\circ}-55^{\circ}$; nervuras intersecundárias tênues; nervuras marginais até $2 \mathrm{~mm}$ da borda, pouco visíveis; pecíolos 5-7 mm compr., adaxialmente sulcados, pilosos. Flores não observadas. Frutos subglobosos, 15-30 mm diâm., multicostados, pilosos, alaranjados quando maduros.

Material examinado: BRASIL. Paraná: São Pedro do Paraná, rio Paraná, 27/X/2002, M.B. Romagnolo 565 (HUEM).

Foram observados frutos em outubro. Segundo Legrand \& Klein (1969), apresenta flores de setembro a novembro.

Eugenia sulcata assemelha-se a E. uniflora por apresentar inflorescência racemosa auxotélica e fruto multicostado, diferenciando-se por apresentar pecíolos mais longos, folhas cartáceas, oblongas, de ápice retuso e frutos pilosos.

$\mathrm{Na}$ área de estudo foi registrado apenas um indivíduo, localizado no paredão de arenito da margem esquerda do rio Paraná. De acordo com Legrand \& Klein (1969), esta espécie desenvolve-se bem nas planícies arenosas do litoral, ocorrendo naturalmente desde o Estado do Rio de Janeiro até o Estado de Santa Catarina.

10. Eugenia uniflora L., Sp. P1. 1: 470. 1753. Fig. 58-65

Nomes populares: pitangueira, pitangueiravermelha, pitanga.

Arvoreta a árvore, ca. 3-10 m alt. Ramos glabros, esfoliantes, pardacentos, lenticelados, os mais jovens avermelhados. Folhas com lâminas 28-45×15-25 mm, razão foliar 1,8-2,7, ovadas, membranáceas, concolores a discolores, glabras, pontos translúcidos mais evidentes adaxialmente, duplolimbinérveas, base obtusa a aguda, ápice agudo a acuminado, margem 


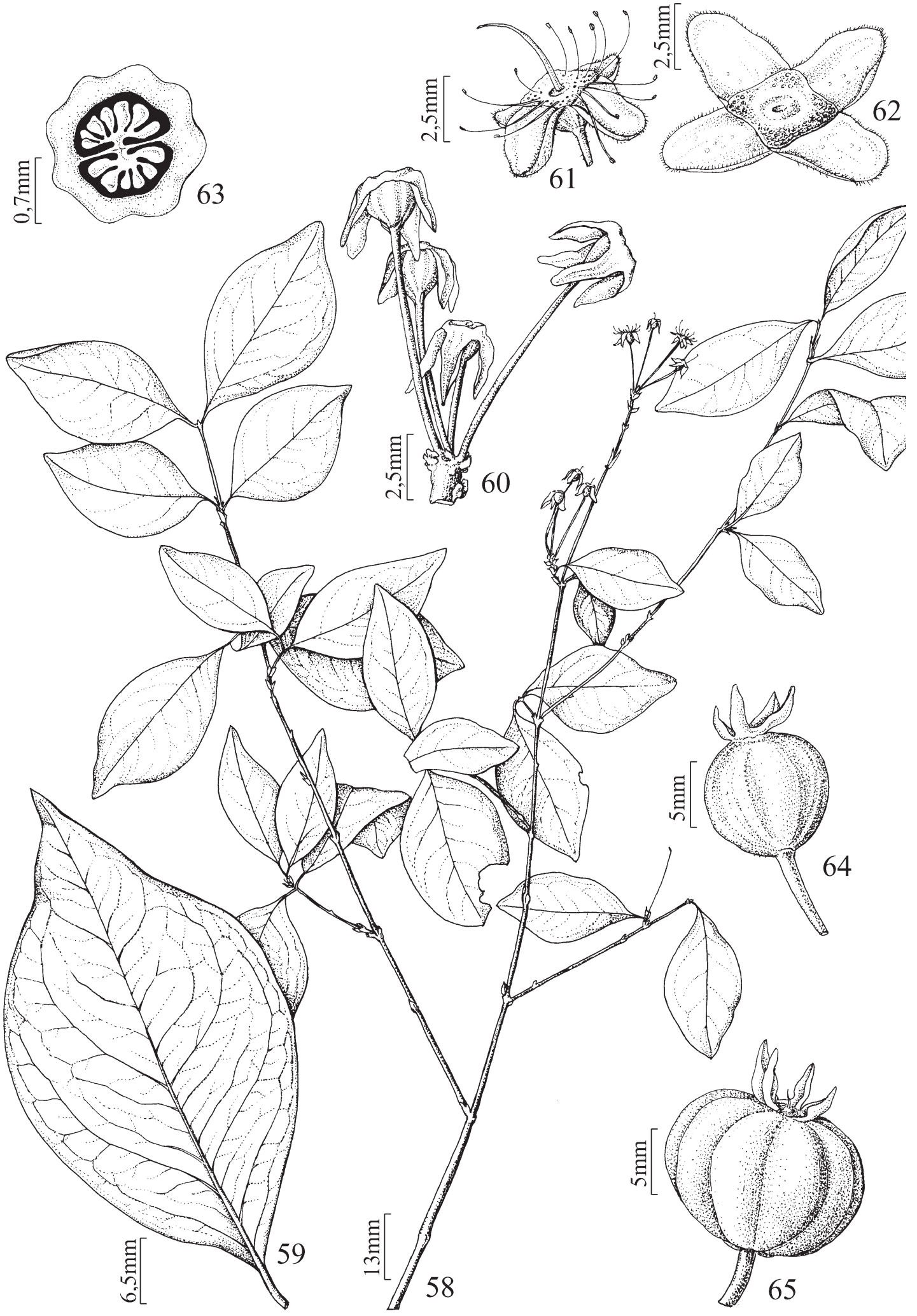

Figuras 58-65. Eugenia uniflora L. 58. Ramo com inflorescência. 59. Folha. 60. Inflorescência. 61. Disco estaminal. 62. Disco estaminal e sépalas. 63. Ovário em corte transversal. 64. Fruto jovem. 65. Fruto maduro (M.B. Romagnolo 655). 
freqüentemente revoluta; nervura central adaxialmente sulcada na porção inferior, freqüentemente avermelhada, abaxialmente proeminente; nervuras secundárias 7-9 pares, avermelhadas, mais evidentes na face abaxial, ângulo de divergência $40^{\circ}-55^{\circ}$; nervuras intersecundárias ramificadas; nervuras marginais até $2 \mathrm{~mm}$ da borda, pouco visíveis; nervuras intramarginais até 1,0 $\mathrm{mm}$ da borda; pecíolos 4-6 $\mathrm{mm}$ compr., adaxialmente sulcados, glabros, avermelhados em material herborizado. Flores 4-7, em racemos auxotélicos, axilares, freqüentemente em ramos com poucas folhas; eixo muito reduzido a ausente; ferofilos ovados, ápice agudo, glabros em ambas as faces, margens ciliadas; antópodio 5-15 mm compr., glabro, freqüentemente brilhante; profilos caducos, ca. $1,2 \times 1,2 \mathrm{~mm}$, fimbriados, ovados a lineares, ápice agudo; botões florais 4-5 mm compr., glabros; sépalas ca. $4,0 \times 2,0 \mathrm{~mm}$, reflexas na antese, oblongas a lanceoladas, ápice obtuso a agudo; pétalas ca. 5,0×3,0 mm, glabras em ambas as faces, obovadas; disco estaminal quadrangular, glabro; estames 3-5 mm compr., glabros; ovário 18-20 ovúlos/lóculo, glabro; estilete 3-4 mm compr., glabro. Frutos subglobosos, 10-15 mm diâm., multicostados, glabros, alaranjados a avermelhados quando maduros.

Material selecionado: BRASIL. Mato Grosso do Sul: Bataiporã, rio Baía, 30/IX/2000, M.B. Romagnolo 655 (HUEM); Jateí, rio Ivinheima, 27/IX/2000, M.B. Romagnolo 627 (HUEM). Paraná: São Pedro do Paraná, ribeirão São Pedro, 24/VIII/2001, M.B. Romagnolo 303 (HUEM).

Foram observadas flores em setembro e outubro, e frutos em outubro. Segundo Marchiori \& Sobral (1997), as variações climáticas costumam influenciar na fenologia, produzindo duas ou mais florações anuais, das quais a mais intensa verifica-se em agosto e setembro, e ocorre juntamente com a emissão de brotos e folhas novas.

$\mathrm{Na}$ área de estudo, Eugenia uniflora, juntamente com E. sulcata, difere das demais espécies por apresentar inflorescências auxotélicas e frutos multicostados. Eugenia sulcata, porém, apresenta folhas oblongas, cartáceas, de ápice retuso, às vezes agudo, e frutos pilosos, o que a diferencia de E. uniflora.

Eugenia uniflora apresenta perda de folhas na estação seca, sendo que as mesmas, quando novas, possuem coloração avermelhada, tendo sido observadas em agosto e setembro. De acordo com Legrand \& Klein (1969), trata-se de uma espécie semidecídua. Em algumas regiões pode ser confundida com E. pitanga, pela semelhança de seus frutos. Porém, essa última apresenta indivíduos de menor porte e maior número de nervuras secundárias e intersecundárias (Legrand 1968; Soares-Silva 2000).

Foi observada apenas nos remanescentes florestais pouco perturbados, na área estudada. De acordo com Rotman (1995), ocorre naturalmente no sudeste e sul do Brasil, na Argentina, no Paraguai e no Uruguai, habita diferentes formações vegetacionais, e demonstra preferência por solos arenosos e úmidos, principalmente nas matas de galeria e nas restingas. $\mathrm{Na}$ maioria das vezes, faz parte das espécies dominantes dos estratos inferiores das florestas (Legrand 1968; Legrand \& Klein 1969; Bernardi 1985; Rotman 1995).

É uma espécie ornamental e frutífera, podendo ser incluída em projetos de revegetação de áreas perturbadas (Reitz et al. 1988; Lorenzi 1992; Marchiori \& Sobral 1997; Backes \& Irgang 2002). Apresenta potencial medicinal, sendo utilizada na medicina caseira como antidiarréica, antitérmica, diurética e hipotensora (Sanchotene 1985; Rotman 1995). Possui óleos essenciais com ação digestiva, sendo utilizada também contra gases e bactérias. Os frutos, ricos em ferro, cálcio e fósforo, são usados para fazer xarope, e as folhas, esmagadas, servem como repelentes contra insetos (Neves \& Donato 1989).

\section{Agradecimentos}

Aos pesquisadores Dra. Lúcia Helena SoaresSilva (UNB) e Marcos Sobral (UFMG), pelo auxílio na identificação das espécies; aos integrantes do laboratório de Mata Ciliar do Nupélia/UEM, pela colaboração nos trabalhos de campo; à Diana Carneiro, pelo auxílio nas ilustrações; ao PEL/CNPq/Nupélia, pelo apoio financeiro.

\section{Referências bibliográficas}

Arantes, A.A. \& Monteiro, R. 2002. A família Myrtaceae na Estação Ecológica do Panga, Uberlândia, Minas Gerais, Brasil. Lundiana 3(2): 111-127.

Backes, P. \& Irgang, B. 2002. Árvores do Sul: guia de identificação \& interesse ecológico. As principais espécies nativas sul-brasileiras. Porto Alegre, CD Vaz e Ricardo Correa.

Barroso, G.M. \& Peron, M.V. 1994. Myrtaceae. Pp. 261-302. In: M.P.M. Lima \& R.R. Guedes-Bruni (orgs.). Reserva Ecológica de Macaé de Cima, Nova Friburgo: RJ. Aspectos florísticos das espécies vasculares. v.1. Rio de Janeiro, Jardim Botânico. 
Berg, O. 1857-1859. Myrtaceae. Pp. 28-208. In: C.F.P. Martius (ed.). Flora Brasiliensis. v.14, pt.1. New York, Verlag von J. Wheldon \& Wesley.

Bernardi, L. 1985. Contribución a la dendrologia Paraguaya II. Boissiera 37: 75-151.

Briggs, B.G. \& Jonhson, L.A.S. 1979. Evolution in the Myrtaceae - Evidence from inflorescence structure. Proceedings of the Linnean Society of New South Wales 102(4): 160-256.

Chagas e Silva, F.; Fonseca, E.P.; Soares-Silva, L.H.; Müller, C. \& Bianchini, E. 1995. Composição florística e fitossociologia do componente arbóreo das florestas ciliares da bacia do rio Tibagi-3. Fazenda Bom Sucesso, Município de Sapopema, PR. Acta Botanica Brasilica 9(2): 289-302.

Embrapa. 1984. Levantamento de reconhecimento dos solos do Estado do Paraná. t.2. Curitiba, Boletim técnico.

Embrapa. 1999. Sistema Brasileiro de Classificação de Solos. Brasília, Embrapa.

Hickey, L.J. 1974. Clasificación de la arquitectura de las hojas de Dicotiledoneas. Boletin de la Sociedad Argentina de Botanica 16(1-2): 1-26.

Iapar. 1994. Cartas Climáticas do Estado do Paraná. Londrina, Iapar.

Johnson, L.A.S. \& Briggs, B.G. 1984. Myrtales and Myrtaceae phylogenetic analysis. Annals of the Missouri Botanical Garden 71: 700-756.

Kausel, E. 1966. Lista de las Myrtaceas y Leptospermaceas argentinas. Lilloa 32: 323-368.

Kawasaki, M.L. 1989. Flora da Serra do Cipó, Minas Gerais: Myrtaceae. Boletim de Botânica da Universidade de São Paulo 11: 121-170.

Klein, R.M. 1984. Importância sociológica das mirtáceas nas florestas rio-grandenses. Pp. 367-375. In: Anais do XXIV Congresso Nacional de Botânica. Porto Alegre 1990. Porto Alegre, Sociedade Botânica do Brasil.

Landrum, L.R. \& Kawasaki, M.L. 1997. The genera of Myrtaceae in Brazil: an illustrated synoptic treatment and identification keys. Brittonia 49(4): 508-536.

Legrand, C.D. 1968. Las Mirtaceas del Uruguay, III. Boletin de la Faculdad de Agronomia 101: 1-80.

Legrand, C.D.J. \& Klein, R.M. 1969. Mirtáceas. Pp. 45-216. In: P.R. Reitz (ed.). Flora Ilustrada Catarinense. Itajaí, Herbário Barbosa Rodrigues.

Leitão Filho, H.F. 1993. Ecologia da Mata Atlântica em Cubatão (SP). Campinas, Editora da Universidade Estadual de Campinas.

Lorenzi, H. 1992. Árvores brasileiras: manual de identificação e cultivo de plantas arbóreas nativas do Brasil. v.1. Nova Odessa, Plantarum.

Lorenzi, H. 1998. Árvores brasileiras: manual de identificação e cultivo de plantas arbóreas nativas do Brasil. v.2. Nova Odessa, Plantarum.

Lunardi, I.; Peixoto, J.L.B.; Silva, C.C.; Shuquel, I.T.A.; Basso, E.A. \& Vidotti, G.J. 2001. Triterpenic acids from Eugenia moraviana. Journal of Brazilian Chemical Society 12(2): 180-183.

Maack, R. 1968.Geografia física do Estado do Paraná. Rio de Janeiro, J. Olympio.
Marchiori, J.N.C. \& Sobral, M. 1997. Dendrologia das Angiospermas: Myrtales. Santa Maria, Universidade Federal de Santa Maria.

McVaugh, R. 1958. Flora of Peru - Myrtaceae. Field Museum Publications on Botany 13(4): 569-819.

McVaugh, R. 1968. The genera of American Myrtaceae, an interim report. Taxon 17(8): 354-418.

Neves, L.J. \& Donato, A.M. 1989. Contribuição ao estudo de Eugenia uniflora L. (Myrtaceae). Bradea 5(25): 273-286.

Paraná. Secretaria de Estado da Agricultura e do Abastecimento, 1987. Atlas do Estado do Paraná. Curitiba, Instituto de Terras, Cartografia e Florestas.

Peixoto, A.L. \& Gentry, A. 1990. Diversidade e composição florística da mata de tabuleiro na Reserva Florestal de Linhares (Espírito Santo, Brasil). Revista Brasileira de Botânica 13: 19-25.

Pio Corrêa, M. 1984. Dicionário das plantas úteis do Brasil e das exóticas cultivadas. v.1. Rio de Janeiro, Instituto Brasileiro de Desenvolvimento Florestal.

Pott, A. \& Pott, V.J. 1994. Plantas do Pantanal. Brasília, Embrapa.

Prioli, A.J.; Panarari, R.S.; Perioto, P.S.; Carlos,V.A.; Prioli, S.M.A.P; Prioli, L.M.; Souza, M.C. \& Romagnolo, M.B. 2002. Molecular pollymorphism in populations of Inga spp. (Mimosaceae), Eugenia spp. (Myrtaceae) e Lonchocarpus guilleminianus (Tul.) Malme (Fabaceae) in Riparian Forest of Upper Paraná River. Pp. 203-206. In: A.A. Agostinho; L.C. Gomes; S.M. Thomaz; L.E. Miranda \& L. Rodrigues (eds.). The Upper Paraná River Floodplain long term ecological research. Maringá, Editora da Universidade Estadual de Maringá.

Radford, A.E. 1986. Fundamentals of Plant Systematics. New York, Harper \& Row.

Reitz, R.; Klein, R.M. \& Reis, A. 1988. Projeto madeira do Rio Grande do Sul. Porto Alegre, SUDESUL-HBR.

Rodrigues, R.R. \& Nave, A.G. 2000. Heterogeneidade florística das matas ciliares. Pp. 45-71. In: R.R. Rodrigues \& H.F. Leitão Filho (eds.). Matas ciliares: conservação e recuperação. São Paulo, Edusp/Fapesp.

Romagnolo, M.B. \& Souza, M.C. 2000. Análise florística e estrutural de florestas ripárias do alto rio Paraná, Taquaruçu, MS. Acta Botanica Brasilica 14(2): 163-174.

Rotman, A.D. 1995. Las especies argentinas del género Eugenia (Myrtaceae). Boletin de la Sociedad Argentina de Botánica 31(1-2): 69-93.

Sanchotene, M.C.C. 1985. Frutíferas nativas úteis à fauna na arborização urbana. Porto Alegre, Fepam.

Soares-Silva, L.H. 2000. A família Myrtaceae - subtribos: Myrciinae e Eugeniinae na Bacia Hidrográfica do Rio Tibagi, Estado do Paraná, Brasil. Tese de Doutorado. Campinas, Universidade Estadual de Campinas.

Souza Filho, E.E. \& Stevaux, J.C. 1997. Geologia e geomorfologia do complexo rio Baía, Curutuba, Ivinheima. Pp.3-46. In: A.E.A.M. Vazzoler; A.A. Agostinho \& N.S. Hahn (eds.). A planície de inundação do alto rio Paraná: aspectos físicos, biológicos e socioeconômicos. Maringá, Editora da Universidade Estadual de Maringá.

Souza, M.C.; Cislinski, J. \& Romagnolo, M.B. 1997. Levantamento florístico. Pp. 345-370. In: A.E.A.M. Vazzoler; A.A. Agostinho \& N.S. Hahn (eds.). A planície de inundação do alto rio Paraná: aspectos físicos, biológicos e socioeconômicos. Maringá, Editora da Universidade Estadual de Maringá. 
Souza, M.C.; Romagnolo, M.B. \& Kita, K. 2004. Riparian vegetation: ecotones and plants comunites. Pp. 330-370. In: A.A. Agostinho; S.M. Thomaz \& N.S. Hahn (eds.). The Upper Parana River Floodplain: physical aspects, ecology and conservation. Leiden, Editora Backhuys.
Stevaux, J.C. 1994. Geomorfologia, sedimentologia e paleoclimatologia do Alto Curso do rio Paraná (Porto Rico, PR). Boletim Paranaense de Geociências 42: 97-112. 